Lester L. Grabbe

\title{
Scribes in the Post-Exilic Temple: A Social Perspective
}

\section{Introduction}

The basic question asked in this conference relates to how the priestly writings developed. This is a scribal question but one on which we have little information. The standard traditio-historical analysis is used by a number of papers in this volume, based on principles developed over a long time. The problem is that the results are hypothetical and depend on colleagues' accepting the result as plausible. What I want to do in this paper is go back to the basics and ask about what we can know about how scribes work. Can we support our traditio-historical results by actual evidence about how scribes carried out their duties?

Thus, in order to throw light on how literature such as Chronicles and the priestly writings may have arisen, an important consideration is the duties of scribes and how they carried them out. Yet a perennial problem is that our actual knowledge of the detailed workings of the Jerusalem temple ${ }^{1}$ in practically any period is very small. On the other hand, scribes functioned in Egypt and Mesopotamian and also in Judah in the later Second Temple period. They also produced a great deal of literature that became conventional, if not canonical. This study will, first, assemble the few data that we have on scribes in the temple and, then, attempt to fill out the picture by cross-cultural comparisons with the work of scribes elsewhere in the ancient Near East. What happened in Judah can only be surmised, but surmise must be based on as much evidence as can be assembled.

One important question is whether this literature is a scribal product, if there was widespread literacy. A recent study suggested that the military hierarchy was literate down to the level of quartermaster. ${ }^{2}$ This study invites a major discussion,

1 It is assumed here that the Jerusalem temple was probably the main place of worship and the location of the largest number of priests and scribes. Other temples also existed in pre-exilic times and are well catalogued for the Persian and Greek periods: Gerizim, Leontopolis, perhaps even Iraq al-Amir across the Jordan.

2 Shira Faigenbaum-Golovin, Arie Shaus, Barak Sober, David Levin, Nadav Na'aman, Benjamin Sass, Eli Turkel, Eli Piasetzky, and Israel Finkelstein, "Algorithmic Handwriting Analysis of Judah's Military Correspondence Sheds Light on Composition of Biblical Texts," PNAS 113/17 (2016): 4664-69.

Lester L. Grabbe, University of Hull 
but it is assumed here that a certain amount of leisure was required to compile, edit, or author texts, which was not the situation of even many literate individuals. Therefore, "scribe" is used here to mean any literate person who deals with the compiling or composition of texts, though it is assumed that this would normally be someone employed in this capacity, i. e., a professional scribe.

\section{The Scribal Model}

Many analogies for understanding the scribal process of producing literature are available to us in recent study in classical, folklorist, and ancient Near Eastern studies. Included here are a look at Mesopotamia, Egypt, and recent study on the Homeric poems, but we begin with the relevant data in the Hebrew Bible and attested for Jews elsewhere.

\subsection{Scribes in the Hebrew Bible}

Although we have no way of confirming the truth of all the statements in the Hebrew Bible, it shall be assumed that they are not far removed from describing the general scribal milieu among the Jews of Palestine from the 7th to perhaps the 4th centuries BCE.

First, a number of passages suggest that many scribes were temple personnel. These are primarily in the books of Chronicles and in Ezra. Levites as scribes are mentioned in a number of passages of Chronicles that have no parallel in Kings (many would argue that these passages should be dated to the Persian period and reflect the situation then): clans of scribes were said to live at Jabez (1 Chron 2:55); Shemaiah b. Nathanel the Levite was a scribe (1 Chron 24:6); the Levitical clans of the Izharites and Hebronites acted as scribal administrators (1 Chron 26:29-32); Jeiel the scribe mustered the army under Uzziah (2 Chron 26:11); some of the Levites were scribes, officials, and gatekeepers (2 Chron 34:13). Ezra is a scribe as well as a priest (Ezra 7:1-6). A scribe called Zadok is appointed to a panel by Nehemiah (Neh 13:13); his name might suggest he is a priest, but other members of the panel are identified as a priest and Levite while he is said only to be a scribe.

The Hebrew Bible assumes scribes were used in the administrations of the kingdoms of Israel and Judah. We know of scribes who were part of the royal administration but are not designated as priests. Some of them may have been part of the temple personnel, but we do not have such information recorded. Seraiah was the main scribe in David's administration (2 Sam. 8:17), or was it 
Sheva (2 Sam. 20:25; 1 Chron. 18:16: Shavsha)? Solomon had Elthoreph and Ahijah, sons of Shisha, which may indicate the office was passed down in families (1 Kgs 4:2). The royal scribe was involved in the donation and use of money for the repair of the temple under the rule of Jehoash (2 Kgs 12:11; 2 Chron 24:11). Shebna, Hezekiah's scribe, was part of the group of officials who listened to the speech of the Rabshakeh (2 Kgs 18:18, 37; 19:2; Isa. 36:3, 22). Hezekiah then sent Shebna with a message to the prophet Isaiah (2 Kgs 19:2; Isa. 37:2). Josiah's scribe Shaphan was centrally involved in the activities surrounding the discovery of the book of the law in the temple and its authentication by the prophetess Huldah, as was Shaphan's son Ahikam (2 Kgs 22:2, 8-12, 14; 2 Chron 34:15, 18, 20). The scribe of the army commander was one of those executed by Nebuchadnezzar ( $2 \mathrm{Kgs}$ 25:19; Jer. 52:25).

Jeremiah has a number of references to scribes: chamber of the scribe in the king's palace (36:12); Elishama the scribe (36:12, 20, 21); Baruch the scribe plays a prominent role $(36: 26,32)$; Jeremiah was imprisoned in the house of Jonathan the scribe $(37: 15,20)$. It is in the book of Jeremiah, however, that it becomes clear that in the last days of Judah a family of scribes were very important in the government and administration of the kingdom, the family of Shaphan. Shaphan was a royal scribe (2 Kgs 22:3, 8; Jer. 36:10-12). This family was an important support for the prophet Jeremiah, with the sons and grandson of Shaphan active in service to him (Jer. 26:24; 36:10-12; 2 Kgs 22:11, 14); for example, Baruch reads the divine words in the chamber of Gemariah son of Shaphan the scribe in the temple (Jer. 36:10). It is not certain that Shaphan was a priest or Levite, but the biblical data do not seem to exclude that possibility. On the other hand, because the king was the leading cultic figure and authority, ${ }^{3}$ it is natural that the royal scribe would be involved in activities relating to the cult and temple, even if he was not of a priestly family.

Things changed after the monarchy ceased, in that there were no longer royal scribes. The scribes described in the biblical text all seem to have been associated with the temple, but there were presumably scribes of the Persian administration, perhaps assisting the provincial governor. Yet there is nothing to prevent there being local people trained for this purpose, even priests.

3 Lester L. Grabbe, Priests, Prophets, Diviners, Sages: A Socio-historical Study of Religious Specialists in Ancient Israel (Valley Forge, PA: Trinity Press International, 1995), 20-40. 


\subsection{Other Scribes in a Jewish Context}

We also have contemporary information in the material culture, beginning at least with the Persian period. Ten seal impressions from a horde sold on the antiquities market have the name "to Jeremai the scribe". ${ }^{4}$ These do not tell us a lot beyond the title, but we also have valuable data from the Jewish community at Elephantine in Egypt. "Scribes of the province" (ספרי מדינתא) are named alongside judges and other officials in a letter to Arsames the governor of Egypt; ${ }^{5}$ we also have references to "scribes of the treasury" (ספרי אוצרא)."6 An individual, whose salary had not been paid and complained to the "officials", was told to complain to the scribes. ${ }^{7}$ Especially interesting are a number of the documents dictated by Arsames: we know he dictated them because the name of the scribe who copied the specific document is also named. ${ }^{8}$ On the other hand, many of the other letters in the collection do not name a scribe, suggesting that the person who sends the letter is also the scribe who wrote it (e.g., in the "Jedaniah Archive"). ${ }^{9}$

\subsection{Scribes in Mesopotamia}

The scribal tradition in Mesopotamia is well documented, including the training of scribes. ${ }^{10}$ As elsewhere scribal duties and positions ranged from the ordinary scribe with the duties of copying texts and perhaps involved in local (village)

\footnotetext{
4 Nahman Avigad, Bullae and Seals from a Post-Exilic Judean Archive, Qedem 4 (Jerusalem: Hebrew University, 1976), 7.

5 Bezalel Porten and Ada Yardeni, Textbook of Aramaic Documents from Ancient Egypt: 1-4, Hebrew University, Department of the History of the Jewish People, Texts and Studies for Students (Jerusalem: Hebrew University, 1986-99), abbreviated TAD: A6.1:1, 6 (= A. Cowley, [1923] Aramaic Papyri of the Fifth Century B.C. [reprinted Osnabruck: Otto Zeller, 1967], abbreviated AP: 17:1, 6).

6 TAD B4.3:13//B4.4:12, $14=A P$ 3:13//2:12, 14.

7 TAD A3.3:5 = BM 4:5.

8 E.g., $T A D$ A6.2:28; A6.8:4; A6.10:10; A6.11:6; A6.12:3; A6.13:5 = AP 26:28; AD 4:4; 7:10; 8:6; 9:3; 10:5.

9 TAD A4.1-10.

10 E.g., Laurie E. Pearce, "The Scribes and Scholars of Ancient Mesopotamia", in Civilizations of the Ancient Near East, ed. Jack M. Sasson (New York: Scribners, 1995), 4: 2265-91; Christopher J. Lucas, “The Scribal Tablet-House in Ancient Mesopotamia," History of Education Quarterly 19 (1979): 305-32; Åke W. Sjöberg, “The Old Babylonian Eduba”, in Sumerological Studies in Honor of Thorkild Jacobsen on his 70th Birthday, ed. Stephen J. Lieberman, AS 20 (Chicago: University of Chicago Press, 1976), 159-79; Samuel Noah Kramer, "Schooldays: A Sumerian Composition Relating to the Education of a Scribe,” JAOS 69 (1949): 199-215.
} 
administration and the lowest level of the bureaucracy up to the ministers of state next to the king. The composing of literature was not in the remit of most scribes, but we have documentation that some scribes had duties of teaching and enhancing scribal skills and knowledge of philology: bilingual word lists needed to be compiled, in part to help apprentice scribes learn to read and copy Sumerian (which had apparently become only a learned language among scholars by about the end of the 2nd millennium BCE). But there were other texts that presented problems, such as divinatory texts and even literary wisdom texts that made use of rare and archaic vocabulary. Thus, one scribal enterprise was to compile commentaries on certain texts. ${ }^{11}$ We also have evidence that some texts were edited to produce new versions for political and perhaps theological reasons. This is documented for the Enuma Eliš, the Babylonian creation epic, with its hero Marduk. Under the Assyrian ruler Sennacherib, the Enuma Eliš (as well as some other texts) were edited to make Aššur the hero of the epic and the chief city Baltil (= Aššur) rather than Babylon. ${ }^{12}$

One of the texts that - perhaps surprisingly - does not have commentaries is the Epic of Gilgamesh. One possible reason for this is that it was not just passed down unchanged but underwent a variety of developments and edits from its origins (perhaps in the mid-3rd millennium BCE). The development of the Gilgamesh story has been investigated at least twice in recent decades. The process can be fairly well documented because of the extent of preservation of copies of the epic over 1500 years.

First was by Jeffrey Tigay ${ }^{13}$ who argues that the story begins with Sumerian texts (perhaps written in the Ur III period in the late 3rd millennium) that narrate individual episodes about Gilgamesh, such as Gilgamesh and the Land of the Living, Gilgamesh and the Bull of Heaven, The Deluge, The Death of Gilgamesh, Gilgamesh and Agga, and Gilgamesh, Enkidu, and the Netherworld. Some of these Sumerian episodes were translated into Akkadian. At some point, an author (apparently a single individual) took either the Sumerian tales or Akkadian translations of the Sumerian material and created the unified Gilgamesh epic in the Old Babylonian period. He did not just compile the epic but edited and rewrote existing material and perhaps even invented material to make a coherent single narrative subordinate to a single primary aim: "The plan of the integrated epic thus testifies to the

11 See especially Eckart Frahm, Babylonian and Assyrian Text Commentaries: Origins of Interpretation, Guides to the Mesopotamian Textual Record 5 (Münster: Ugarit-Verlag, 2011).

12 Frahm, Babylonian and Assyrian Text Commentaries, 347-54.

13 Jeffrey H. Tigay, The Evolution of the Gilgamesh Epic (Philadelphia: University of Pennsylvania Press, 1982). 
working of a single artistic mind". ${ }^{14}$ After the developments in the Old Babylonian period, the epic continued to develop in a Middle Babylonian version, a late version that contains the flood story, ${ }^{15}$ and the version in Berossus. ${ }^{16}$

More recently Daniel Fleming and Sara Milstein argue that the "Huwawa narrative" is at the core of the epic's growth. ${ }^{17}$ They do not appear to rule out an oral stage, but an earlier Sumerian version of the tale was turned into an Akkadian version in the Old Babylonian period (early 2nd millennium BCE). This Akkadian version was not, however, a simple translation of the Sumerian but a new independent creation. This had material added before and after it, with some re-editing of the Huwawa narrative itself, to create the fuller Gilgamesh epic in the Old Babylonian period. Their study stops at this point and does not trace the further development of the epic after the Old Babylonian period.

In spite of the differences of the two analyses just outlined, there are substantial agreements. It seems clear that there was an oral stage of Gilgamesh traditions in the half millennium between a historical Gilgamesh, who seems to have been king of Uruk somewhere in the period 2700-2500 BCE, and the earliest Sumerian written texts with these traditions in the Ur III period. How the oral tradition was passed down and how it came to be written down are questions to which we have no answer. But it does seem that such an oral period of the various Gilgamesh traditions did exist. After the developments in the Old Babylonian period (as discussed above), the epic continued to develop, with a Middle Babylonian version, a late version that contains the flood story, and finally the version in Berossus.

\subsection{Scribes in Egypt}

The development of writing and scribalism in Egypt is well documented over three millennia and more. ${ }^{18}$ In Egyptian inscriptions "scribe" and "administrator" are often used interchangeably. Briefly, scribes were initially in the service of the king and also took care of the affairs of the administration. They had a variety of different functions, just as the higher officials in the administration had functions dif-

14 Tigay, The Evolution of the Gilgamesh Epic, 42.

15 ANET 72-99, probably dated to the late 2nd millennium.

16 Stanley M. Burstein, The Babyloniaca of Berossus, SANE 1/5 (Malibu: Undena, 1978), late $4^{\text {th }}$ century BCE.

17 Daniel E. Fleming and Sara J. Milstein, The Buried Foundation of the Gilgamesh Epic: The Akkadian Huwawa Narrative, Cuneiform Monographs 39 (Leiden: Brill; Atlanta: SBL Press, 2010). 18 E.g., Adelheid Schlott, Schrift und Schreiber im Alten Ägypten, Beck’s Archäologische Bibliothek (Munich: Beck, 1989). 
ferent from the ordinary scribe at the bottom of the ladder, as their titles show ${ }^{19}$ : at the lower level were those scribes who recorded the numbers of cattle or the yield of the harvest (primarily for tax purposes) and perhaps wrote letters for the illiterate at the village level. At the top were the high officials next to the king, but they employed a "middle level" of scribes who did the actual work of writing, recording, and translating. Although there are examples in which scribes rose in status in the hierarchy, generally the sons of those at the bottom of the hierarchy themselves remained also at the bottom, and so on.

In the New Kingdom a number of high scribes were responsible for recruiting for the army and even leading it as generals. ${ }^{20}$ The Israelite "scribe of the army" had a similar function of "recruiting the people of the land (for the military)" (2 Kgs 25:19; Jer. 52:25). Because their tombs have been preserved, we have the "autobiographies" of some Egyptian high officials who designate themselves as scribes (e.g., Rechmire ${ }^{21}$ ). Military campaigns required a number of ordinary scribes to keep the "palace day book" in which the deeds of the king were recorded with regard to military operations (e. g., Thutmose $\mathrm{III}^{22}$ ).

When we look at the literature produced, we find a variety of genres. An important scribal product is the range of writings produced or selected as useful for teaching apprentice scribes. ${ }^{23}$ In the First Intermediate Period we find writings, such as the Admonitions of Ipuwer or the Prophecies of Neferti, which have been interpreted as an expression of the consternation felt by many during those troubled times, ${ }^{24}$ though not everyone agrees. ${ }^{25}$

We have another model for which we have good deal of information from the Ptolemaic period: the village scribe. We shall focus on one particular archive here,

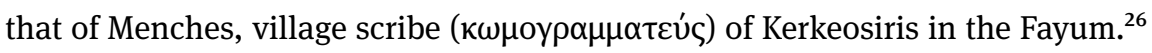

19 Schlott, Schrift und Schreiber im Alten Ägypten, 93-94.

20 Schlott, Schrift und Schreiber im Alten Ägypten, 217-37.

21 See Lexikon der Ägyptologie 5:180-82.

22 Miriam Lichtheim, Ancient Egyptian Literature: Volume II: The New Kingdom (Berkeley/Los Angeles: University of California Press, 1976), 29-35.

23 Schlott, Schrift und Schreiber im Alten Ägypten, 196-208.

24 Schlott, Schrift und Schreiber im Alten Ägypten, 182-96.

25 Miriam Lichtheim, Ancient Egyptian Literature: Volume I: The Old and Middle Kingdom (Berkeley/Los Angeles: University of California Press, 1973).

26 A lengthier discussion of this figure is given in Lester L. Grabbe, "Scribes, Writing, and Epigraphy in the Second Temple Period", in "See, I Will Bring a Scroll Recounting What Befell Me" (Ps 40:8): Epigraphy and Daily Life from the Bible to the Talmud, Dedicated to the Memory of Professor Hanan Eshel, Journal of Ancient Judaism Supplement 12, ed. Esther Eshel and Yigal Levin (Göttingen: Vandenhoeck \& Ruprecht, 2014), 105-21. A basic study is A. M. F. W. Verhoogt, Menches, Komogrammateus of Kerkeosiris: The Doings and Dealings of a Village Scribe in the Late 
Menches first comes to our attention in a papyrus of about 120 BCE when his term of office is renewed, indicating that he had already held the office for an unknown period previously. A letter of appointment was written by the chief royal scribe ( $\beta \alpha \sigma \iota \lambda \iota \kappa o ̀ \varsigma ~ \gamma \rho \alpha \mu \mu \alpha \tau \varepsilon u ́ \varsigma)$ to the chief scribe of the toparchy. ${ }^{27}$

We do not know how Menches got the office. There is some evidence that he knew or was related to someone substantial in the bureaucracy. ${ }^{28}$ The main duty of the village scribe was to oversee the agricultural taxes of the area. For this, detailed records of each property were kept, including its dimensions and ownership. Crown land would be rented out, but non-crown land was subject to taxes of various sorts. Taxes varied, depending on the crops being grown - even whether the tax would be paid in kind or in silver. Thus, a careful record had to be kept even of the types of crops being planted.

The village scribe was part of a hierarchical network of scribes, answerable to the toparchy scribe (topogrammateus) and the chief royal scribe (basilikos grammateus) who was above the toparchy scribes. This could lead to a dressing down for not "respecting" the office of his superior, as in a letter in which a relative of the toparchy scribe was alleged to have been given no special treatment. ${ }^{29}$ Menches also found himself on the receiving end of various complaints and excuses by those over whom he had responsibility for taxes and the like. ${ }^{30}$ Another complaint was of an even more blatant offence, that of breaking into a house and committing armed robbery. ${ }^{31}$ Menches himself was not immune from serious legal charges, as is indicated by a petition that he made to the king and queen themselves. He had been arrested because of an accusation of poisoning

Ptolemaic Period (120-110 B.C.), Papyrologica Lugduno-Batava 29 (Leiden: Brill, 1998). A recent study of village scribes that uses other examples, as well as Menches, is found in Giovanni B. Bazzana, Kingdom of Bureaucracy: The Political Theology of Village Scribes in the Sayings Gospel Q, BETL 274 (Leuven: Peeters, 2015); his main interest is in applying the model to the origin of the hypothesized Q document.

27 Bernard P. Grenfell, Arthur S. Hunt, and J. Gilbart Smyly (eds.), The Tebtunis Papyri, Part I, University of California Publications, Graeco-Roman Archaeology 1; Branch (London: Henry Frowde, 1902): 72-73 (text no. 10); see also the translation in Verhoogt, Menches, Komogrammateus of Kerkeosiris, 60.

28 Cf. Grenfell, et al. (eds.), The Tebtunis Papyri, Part I, 70-71.

29 Grenfell, et al. (eds.), The Tebtunis Papyri, Part I, 94-95 (text no. 23).

30 Grenfell, et al. (eds.), The Tebtunis Papyri, Part I, 157-59 (text no. 50); see also the translation in Roger S. Bagnall and Peter Derow (eds.), The Hellenistic Period: Historical Sources in Translation, Blackwell Sourcebooks in Ancient History 1 (Oxford: Blackwell; new edn, 2004), 175.

31 Grenfell, et al. (eds.), The Tebtunis Papyri, Part I, 152-53 (text no. 46); see also the translation in Naphtali Lewis, Greeks in Ptolemaic Egypt: Case Studies in the Social History of the Hellenistic World (Oxford: Clarendon, 1986), 121. 
against him; however, the charges were dismissed because the accusers failed to appear when the court sat. But Menches appealed to royalty so that the same or further charges would not be made against him. ${ }^{32}$

Although Kerkeosiris was only a village of about 1500 persons, the duties of the village scribe were not carried out in an obscure corner. On the contrary, there was regular correspondence not only with the toparchy scribe but even with the chief royal scribe. Preserved are a number of letters to the various individuals who held the office of topogrammateus during the period that Menches held office. Yet the greatest portion of Menches' outgoing correspondence was to the basilikos grammateus. The village scribe apparently had the responsibility of letting the chief royal scribe know immediately whenever something went wrong, and the date on the reports indicates they were done with dispatch. In one case, a matter was apparently reported when Menches and Horus the basilikos grammateus were together, since it concerned Menches' own village. As soon as he had further information, Menches made a "supplementary report" to Horus to keep him informed. ${ }^{33}$

In the interests of communication - though the ultimate concern was maximizing state revenue - there was evidently an annual meeting in Alexandria, in which all the toparchy scribes and some of the village scribes made the journey down river to report to the chief royal scribe. However often Menches made this journey is not known, but at least one letter seems to order him to do so. ${ }^{34}$

To summarize briefly, the village scribe held an important office and was responsible for keeping track of records in the local area, especially relating to the assessing and collection of taxes on crops. This would also have applied specifically to village scribes in Judah but also in general to scribes in other spheres. Even though the village scribe will not provide our main model, many scribes had not only the important function of record keeping but also often a significant role in administration. This scribal model is important.

32 Grenfell, et al. (eds.), The Tebtunis Papyri, Part I, 146-49 (text no. 43); see also the translation in Lewis, Greeks in Ptolemaic Egypt, 116-17.

33 James G. Keenan and John C. Shelton (eds.), The Tebtunis Papyri, Volume IV, Graeco-Roman Memoirs 64 (London: Egypt Exploration Society, 1976), $27-29$ (text no. 1099); see also the translation in Verhoogt, Menches, Komogrammateus of Kerkeosiris, 91.

34 Grenfell, et al. (eds.), The Tebtunis Papyri, Part I, 103-5 (text no. 26). 


\subsection{Example of Homeric Poems}

A recent study on the origins of the Homeric poems is Jonathan Ready's Orality, Textuality, and the Homeric Epics; ${ }^{35}$ one of its values is that it summarizes some of the debate on the origins of the Iliad and the Odyssey and also draws on a good deal of comparative studies, especially modern studies relating to oral literature in various parts of the world. As I shall suggest, some aspects of Homerica study have very interesting implications for the study of the origins of biblical literature; on the other hand, there are also crucial differences, especially when we investigate certain genres of biblical writings.

Two main theories about how the Homeric poems became written down are discussed by Ready. ${ }^{36}$ One is the "dictation theory", which suggests that a poet dictated, i.e., performed or recited, the poem to a scribe. One variation on this (that of M. L. West) is that the poet himself acted as the scribe or perhaps engaged a scribe as an amanuensis. The other is the "evolutionary theory", in which various versions of the poems were written down, beginning at an early date, though these eventually produced a standardized version by a process of editing.

According to Ready's thesis, the written text is a product of a three-way interaction between the collector or sponsor, the poet, and the scribe. In some cases the "collector" might be the poet himself who enlists the scribe to take down the poem in writing. The poet is of course normally performing his recitation before an audience and interacting with that audience. The environment in the process of dictation would be different, even if there was still an audience. The poet would have to give the scribe time to write down the text, which would slow the process of recitation down considerably. It was also likely to make him more self-aware of his poetry and more reflective on its content, perhaps leading to some self censorship.

\subsection{Summary about Scribes}

The following points seem to be suggested by the data examined above:

- Although they were not always distinguished, it appears that there were different types of scribes: those whose job was primarily to copy, though they might well take dictation; scribes who drafted correspondence; village scribes

35 Jonathan L. Ready, Orality, Textuality, and the Homeric Epics: An Interdisciplinary Study of Oral Texts, Dictated Texts, and Wild Texts (Oxford: Oxford University Press, 2019).

36 Ready, Orality, Textuality, and the Homeric Epics, 101-4. 
who were responsible locally, especially in assessing and collecting taxes; scribes who had important administrative responsibilities high up in government; and, finally, scribes who composed and edited literature. The types of scribe varied, of course, from culture to culture. Scribes often seemed to have more than one task, but only the elite, with more leisure time, were probably involved in composing or editing writings to be passed down.

- Many scribes in Judah seem to have been members of the priestly cast, whether altar priests or lower clergy (Levites). Scribes in the temple would have been trained by priests. There are also indications that the scribal office was often passed down from father to son, and training was probably a form of apprenticeship.

- Some scribes were important figures in the administration of the kingdoms of Israel and Judah, as indicated by a number of biblical passages. Similarly, once Judah became a province in the Persian and the Hellenistic empires, with the high priest as the highest native figure, some scribes were high up in the local government. Some scribes in the royal administration may not have been priests, but many even of these scribes were probably priests. Similarly, during the Persian and Hellenistic periods, some of the scribes might still have been temple personnel.

- The komogrammateus or village scribe is well documented in Egypt, and these data have been plausibly extrapolated to other regions. This is probably not a good model for the origins of most Jewish literature, however, since village scribes were not likely to be involved in the composition of literature. Such religious and literary writings were probably more often the product of priestly scribes.

- In Mesopotamia such writings as the Epic of Gilgamesh and the Enuma Elish give examples of how literature might develop in the scribal sphere. Gilgamesh moved from a (hypothetical) oral stage to Sumerian tales to a first (hypothetical) Akkadian version of the Huwawa tale to the full Gilgamesh epic. Similarly, we see the Babylonian creation epic deliberately edited by Assyrian scribes (probably under Sennacherib) to produce an "Assyrianized" version that makes the god Aššur the hero of the tale.

- Some of the work being done on the development of the Homeric poems and their transfer from the oral sphere to writing helps us to understand how oral tradition can become written literature. An important aspect of this is the question of dictation, since the person with knowledge of the oral tradition might dictate to a scribe. An example of this is already found in the figures of Jeremiah and Baruch. 


\section{Scribes and the Production of Literature}

It seems clear that much of the literature that we possess from antiquity is a scribal product. It may be that a book like Qohelet was written by perhaps a literate member of the upper classes rather than by a professional scribe, but this would have been exceptional in the ancient Near East, especially before the Hellenistic period. In the Greco-Roman world we have many writings authored by individuals who were playwrights, philosophers, poets, and historians who did not belong to the scribal profession as such. Nevertheless, when we are looking at the vast bulk of Jewish literature from antiquity, we appear to be viewing a scribal product. The survey of scribalism in the previous section has thrust upon us a number of possible models for the production of the Hebrew Bible and other Jewish literature. We can now consider the usefulness of some of these.

The model of the village scribe is interesting because we have a good deal of information on the office. It has also been used recently as a means of postulating the origin of the hypothetical Q source in the gospels of Matthew and Luke. This thesis might work well with the $\mathrm{Q}$ gospel source (though this is a matter for NT scholars to debate). Yet it seems unlikely that it will help us with the origin of parts of the Hebrew Bible, which are more likely to be the product of temple scribes.

Work done over the past century and more on the Homeric poems may help us. It shows us that great literature might have had an oral stage, perhaps even narratives of considerable length only in oral form. The problem with this model is that the narratives we are investigating in this conference are not poetry and are not likely to have had an origin as poetry. On the other hand, an oral stage for some or much of the material is a reasonable assumption. Also, some of the recent discussion of the Homeric epics has emphasized the importance of considering a dictation model, in which the oral material is reduced to writing by the oral poet's dictation of it to a professional scribe. This is important because we have evidence that certain writings from the late monarchy and the Persian period were dictated by individuals to scribes. For example, Jeremiah is pictured as dictating some of his prophecies to Baruch (Jer. 36). At Elephantine Arsames dictated letters to a scribe, as we know from the letters preserved that give the name of the scribe. Such would have been easier than for an oral poet to perform the Iliad or the Odyssey with a scribe taking it down in writing. We shall return to this point below. 


\section{Examples of Scribal Literary Development}

Of particular importance are examples of writings that show actual evidence of scribal development. There are few of these, sadly, but there are some. Here are four such examples that show development that can be catalogued and is not just hypothesized.

First, there is the Gilgamesh epic, which was discussed at length above. ${ }^{37}$ Its investigation is important because the evolution of the epic is significantly documented. There are still gaps that have to be filled, but its development over perhaps 1500 years can be observed in ways that Hebrew Bible scholars can only dream of because the many copies have given us variant versions, some of which seem to be intermediate between others. Therefore, even though the process of editing is nowhere described, it can be inferred from the various copies of the epic over the centuries. What we find is that the original 3rd-millennium Sumerian tale (the "Huwawa story") - which probably had an oral stage - was turned into Akkadian at the beginning of the 2nd millennium in the Old Babylonian period, but the Akkadian version was not a translation of the Sumerian tale as such but a new creation by the "translator" who retold the story in his own words. The story was then further adapted by having other narratives relating to Gilgamesh edited before and after it, to give an epic of Gilgamesh.

What this model indicates is that narratives or other traditional elements can - indeed, usually do - evolve over time, normally becoming longer and more detailed in the later stages. This has long been the hypothesis in Hebrew Bible studies but, unfortunately, often difficult to find concrete evidence for it. This is why such models are so important.

This general statement is also illustrated by the book of Jeremiah. Much work has gone into proposing how the book arose at the hypothetical level. For our purposes, though, two stages in this development seem to be preserved in the Septuagint version and the Hebrew Masoretic version. There is wide agreement that the LXX version represents an earlier stage in the writing of the book. ${ }^{38}$ This is based not only on comparing the Greek and Hebrew versions but also Qumran manuscript 4QJer ${ }^{\mathrm{b}}$ (4Q71). This is a very fragmentary version, but at Jeremiah 9:2110:22(?) the Qumran manuscript follows the LXX text in lacking verses 6-8 and 10

37 See under the heading, "Scribes in Mesopotamia".

38 E.g., J. Gerald Janzen, Studies in the Text of Jeremiah, Harvard Semitic Monographs 6 (Cambridge, MA: Harvard University Press, 1973); William McKane, A Critical and Exegetical Commentary on Jeremiah: Volume I Introduction and Commentary on Jeremiah I-XXV, ICC (Edinburgh: T \& T Clark, 1986); Robert P. Carroll, Jeremiah: A Commentary, OTL (London: SCM, 1986). 
and having verse 9 between $5 a$ and $5 b .^{39}$ This is a good example illustrating that the LXX translator of Jeremiah was not abbreviating his Hebrew Vorlage but translating it faithfully. With a text one-eighth shorter than the MT, the original Hebrew text of the LXX has been considerably expanded by later scribes to give us the MT.

Another example focuses on Daniel 4. Already in 1935 Wolfram von Soden argued that the legend of Nabonidus lay behind Daniel's story. ${ }^{40}$ The Nabonidus Chronicle was available to him, ${ }^{41}$ then in the next couple of decades surprising new information confirmed von Soden's inspired proposal. One was the discovery of the Harran inscription in 1956 in which Nabonidus's stay in the area of Teman toward the end of the Neo-Babylonian period in quest of the god Sin was described. ${ }^{42}$ Nabonidus's actions were interpreted by many in the establishment of Babylon as madness, especially as exemplified in the Verse Account of Nabonidus. ${ }^{43}$ Some years later a text found among the Qumran scrolls was published, the 4QPrayer of Nabonidus (4Q242), which was a story of the Babylonian king Nabonidus being ill for seven years but cured by a Jewish exorcist. What we now have are three stages in the story:

(i) Story of Nabonidus's religious quest of ten years in Teman (this may have been only an oral stage circulating in Babylon but is supported by the official accounts): (a) Harran inscriptions: Nabonidus's official statement about what he was doing; (b)The Nabonidus Chronicle: the official account of Nabonidus's reign. (ii) 4Q242: Nabonidus's strange behavior has become an illness, and his ten years in Teman have become seven of illness. (iii) Daniel 7: Nabonidus has become Nebuchadnezzar, and the Jewish exorcist from the exiles has transformed into the dream interpreter Daniel.

There may not be a linear development in the surviving documents, that is, Daniel 4 may not be a direct literary development from 4Q242 (or its ancestors), but each represents a stage in the development of the tradition that became Daniel 4 from the original story of Nabonidus. ${ }^{44}$

39 Emanuel Tov, “Three Fragments of Jeremiah from Qumran Cave 4,” Revue de Qumran 15 (1992): 531-41.

40 Wolfram von Soden, "Eine babylonische Volksüberlieferung von Nabonid in den Danielerzählungen,” ZAW 53 (1935): 81-89.

41 See especially Albert K. Grayson, Assyrian and Babylonian Chronicles, Texts from Cuneiform Sources 5 (Locust Valley, NY: J. J. Augustin, 1975), 104-11.

42 ANET 560-63.

43 ANET 312-15.

44 Further discussion can be found in Matthias Henze, The Madness of King Nebuchadnezzar: The Ancient Near Eastern Origins and Early History of Interpretation of Daniel 4, JSJSup 61 (Leiden: Brill, 1999); Carol A. Newsom, "Why Nabonidus? Excavating Traditions from Qumran, the 
The final example concerns the Qumran and Cairo Genizah texts of the Damascus Document. ${ }^{45}$ Already the two copies found in the Cairo Genizah (CD) raised questions about the relationship of their texts, but the discovery of approximately ten copies at Qumran has made it clear to many that there were developments in the text over time. The "Admonition" section (CD 1-8, 19-20) would presumably have needed periodic updating because it contained the regulations about a closed community and its organization. The "Laws" section (CD 9-16) seems to have been more stable, but both sections have now been studied from a traditio-historical perspective.

Already it was determined that CD 19-20 and 15-16 should probably be placed between CD 8 and CD 9. Then 4QD ${ }^{\mathrm{a}}$ (= 4Q266) demonstrated a much fuller version of the Damascus Document. It apparently has both the beginning and end of the text, based on the physical presentation of the manuscripts. It demonstrates the order CD 1-8, 19-20, 15-16, 9-14, but it also shows that a section of text beginning the document is not found in CD (at least, as preserved); it also has an ending not found in $C D$. $4 Q^{\mathrm{a}}$ preserves a section of text that preceded CD 1.1. 4QD , along with 4QD ${ }^{\mathrm{b}}$ (4Q267), 4QD (4Q268), 4QD ${ }^{\mathrm{d}}$ (4Q269), 4QD $\mathrm{D}^{\mathrm{e}}$ (4Q270), 4QD $\mathrm{Q}^{\mathrm{f}}$ (4Q271), 4QD (4Q272), and 4QpapD ${ }^{\mathrm{b}}$ (4Q273), also give various statements in the "Laws" section which add further regulations not addressed in CD, including disqualifications for various categories of priests, on diseases, on agriculture, on the jubilee years, clothing for male and female, appropriate marriages, to name some of them. Of particular interest is that $4 \mathrm{QD}^{\mathrm{e}}$, frag. 7, i.1-21, is parallel to the Community Rule (1QS 7.12-21), as is $4 \mathrm{QD}^{\mathrm{d}}$ parallel to $1 \mathrm{QS}$ 7.14-18. It has often been felt that the Damascus Document and the Community Rule were somehow related, though few studies seem to have demonstrated this in any detail.

A number of different traditio-historical analyses of the Damascus Document have appeared over the years, which will not be discussed further here. ${ }^{46}$ Most of those dealing with the "Admonition" section were done before the Qumran texts became available. The main point, though, is that in the variety of versions now available we seem to see the text developing over time. In this case, the shorter version - CD - is much later than the earlier (Qumran) versions. It may be that CD has been accidentally abbreviated rather than deliberately shortened, though we

Hebrew Bible, and Neo-Babylonian Sources", in The Dead Sea Scrolls: Transmission of Traditions and Production of Texts, STDS 92, ed. Metso, Sarianna, Hindy Najman, and Eileen Schuller (Leiden: Brill, 2010), 57-79.

45 See especially Charlotte Hempel, The Laws of the Damascus Document: Sources, Tradition, and Redaction, STDJ 29 (Brill: Leiden, 1998); Charlotte Hempel, The Damascus Texts (Sheffield Academic Press, 2000).

46 See the survey in Hempel, The Damascus Texts, 44-53. 
cannot be absolutely sure..$^{47}$ In any case, the later version of an edited work is not invariably longer; this is only a tendency. Further study may show a complicated development of this text of the Damascus Document.

\section{My Proposal for Connecting Chronicles and P}

With regard to $\mathrm{P}$, it was probably compiled in the early Persian period, though those members of the "Kaufmann school" who see pre-exilic signs in P are probably right about some or even much of the material in P. But the final product is probably post-exilic, or more likely from the Persian period. ${ }^{48}$ If the standard theory (based on Graf-Wellhausen) is accepted, P included a variety of material: directions and descriptions relating to the temple and the cult but also genealogies and narrative material about Israel's past. Priests were interested in giving their own take on Israel's early history, including creation, the primordial period, the post-flood renewal, the patriarchs, and Israel's removal from Egypt to the Promised Land. The classic P hypothesis does not just propose cultic and ritual regulations; it also includes narrative - a Heilsgeschichte beginning with creation and leading up to entry into the promised land. The creation story in Genesis 1 seems to be cognizant of the Babylonian creation epic the Enuma Eliš. I have argued that a version of the Pentateuch that we now know was compiled in the Persian period, probably in the 4th century BCE, perhaps including the participation of Ezra the priest and scribe. ${ }^{49}$ The Deuteronomistic History (DH) seems to

47 Hempel, The Damascus Texts, 24.

48 See especially the commentary of Erhard S. Gerstenberger, Leviticus: A Commentary, OTL (Louisville, KY: Westminister John Knox, 1996); ET of Das dritte Buch Mose: Leviticus, Das Alte Testament Deutsch 6 (Göttingen: Vandenhoeck \& Ruprecht, 1993), which argues the case well. The massive commentary by Jacob Milgrom, Leviticus 1-16: A New Translation with Introduction and Commentary, AB 3 (Garden City, NY: Doubleday,1991); Jacob Milgrom, Leviticus 17-22: A New Translation with Introduction and Commentary, AB 3A (New York: Doubleday, 2000); Jacob Milgrom, Leviticus 23-27: A New Translation with Introduction and Commentary, AB 3B (New York: Doubleday, 2001) argues that P fitted the pre-monarchic phase of Israel, which reflects the small size of the territory. Granted that P seems designed for a small political entity in Palestine, the Persian province is a better fit with the known data (especially the language used) than the alleged pre-monarchic entity.

49 See especially Lester L. Grabbe, "The Last Days of Judah and the Roots of the Pentateuch: What Does History Tell Us?” in The Fall of Jerusalem and the Rise of the Torah, FAT 107, ed. Peter Dubovský, Dominik Markl, and Jean-Pierre Sonnet (Tübingen: Mohr Siebeck, 2016), 19-45; also Lester L. Grabbe, "Elephantine and the Torah”, in In the Shadow of Bezalel: Aramaic, Biblical, and Ancient Near Eastern Studies in Honor of Bezalel Porten, Culture and History of the Ancient Near 
have been compiled before the end of the Neo-Babylonian period, though some would want to put it in the early Persian period. ${ }^{50}$

The composer(s) of Chronicles (Chr) probably worked in the early Hellenistic period and thus perhaps a century or even two after P. But he/they already had available to him/them a "history" as laid out in the Pentateuch and DH that extended from creation to the fall of Jerusalem in 587/586 (at least, in outline form, if not as detailed as in the present texts). But to Chr there were some deficiencies in this history, because it did not say enough about the temple and priesthood. Thus, Chr set out to write a version more congenial to their concerns. Whether Chr had P available as a separate document, rather than just as a part of the completed Pentateuch is unlikely, but it is not impossible.

Chr did not repeat the first part of this history as such, but covered it by means of the extended genealogies in 1 Chron. 1-9. Whether it was revised independently from a version of Samuel-Kings, ${ }^{51}$ as is conventionally assumed, or had a base text that had been revised by the author of Samuel-Kings (so A. G. Auld argues, based on De Wette ${ }^{52}$ ), it was important to link the organization of the temple and priesthood to David, the first "proper" king of the people. The author was probably a member of the priesthood or at least someone close to the temple and priests (cf. the later author Ben Sira). In any case, Chr also may have remembered that under the monarchy, the king was the highest cultic official, and all the priests (including the high priest) ultimately answered to him..$^{53}$ Some members of the priesthood wanted to present the king as subject to the priests (e.g., Deut.

East 60, ed. Alejandro F. Botta (Leiden/Boston: Brill, 2013), 125-35. On the question of Ezra, see Lester L. Grabbe, "Penetrating the Legend: in Quest of the Historical Ezra”, in Open-Mindedness in the Bible and Beyond: A Volume of Studies in Honour of Bob Becking, LHBOTS 616, ed. Marjo C. A. Korpel and Lester L. Grabbe (London and New York: Bloomsbury T \& T Clark, 2015), 97-110. 50 Cf. especially Thomas C. Römer and Albert de Pury, "Deuteronomistic Historiography (DH): History of Research and Debated Issues”, in Israel Constructs its History: Deuteronomistic Historiography in Recent Research, JSOTSup 306, ed. Albert de Pury, Thomas Römer, and Jean-Daniel Macchi (Sheffield: Sheffield Academic Press, 2000), 24-141, for a discussion of Noth's original thesis and the subsequent developments of the theory.

51 It has been rightly argued that the version of Samuel-Kings used in such a hypothesized revision would have been different from the recension in the Masoretic text (e. g., Werner E. Lemke, "The Synoptic Problem in the Chronicler's History", HTR 58 [1965]: 349-63). But it would probably not have been significantly different. Much of the text of Chronicles not found in Samuel-Kings was probably contributed by $\mathrm{Chr}$ himself rather than being in the base text he was revising.

52 A. Graeme Auld, Kings without Privilege: David and Moses in the Story of the Bible's Kings (Edinburgh: T \& T Clark, 1994).

53 Grabbe, Priests, Prophets, Diviners, Sages, 20-40. 
17:14-20), but this was evidently not the view of Chr - at least, as far as David was concerned. ${ }^{54}$

It is David himself who not only gathered all the material for building the temple but also organized the priesthood and the cultic service, according to 1 Chron. 22-28. Not much was left for Solomon to do, if 1 Chronicles is anything to go by! The history of the monarchy emphasizes the place of the priests and the existence of all sorts of prophets and holy men not found in 1 and 2 Samuel and 1 and 2 Kings. What this suggests is that Chr, although probably (a) priest(s) or Levite(s), belonged to a different school from the compilers of P. Or perhaps it was just that Chr was a generation or more removed from the P school and saw things differently because of the change in circumstance with regard to the priests in the early Hellenistic period.

It seems clear that priestly knowledge was passed down orally, i. e., by apprenticeship. There would have been no need to write it down: it was preserved in the collective minds of the priests and handed on by teaching and example to the new generations of priests learning their trade. Writings such as Leviticus are clearly not for temple personnel but for the wider Israelite community, though based (in part, at least) on priestly knowledge and practice. This means that at some point this oral tradition and practice was reduced to writing, specifically to educate the non-priestly lay Israelites. It might have been a senior priest who wrote it down, but it could well have been that a senior priest dictated the material to a younger priestly scribe.

Thus, the picture of the temple given by the priestly writer(s) of Chronicles is inspired in part by the P section of the Pentateuch, but also by the knowledge of the priestly tradition available to scribes, current cultic practice in the temple and, finally, Chr's utopian imagination of the temple state that he would like to have seen in his own day.

\section{Conclusions}

The present study could only go so far because of the sporadic nature of the evidence. I have drawn attention to the hypothetical nature of the standard traditio-historical analysis. Yet the present paper has been disappointing in that

54 It must be admitted that Uzziah is presented as being cursed by God with a disease because of trying to offer sacrifices in the temple (2 Chron 26:16-21), even though Solomon and David had done the same thing (1 Chron 21:28; 2 Chron 1:6). He may, therefore, have distinguished between David and subsequent kings of Judah. 
it has not been able to obviate the hypothetical aspect of our textual analysis: conjecture and hypothesis have also been a necessary part of this study. Only in four examples has it been possible to provide actual demonstration of some textual development. Also, this study's results might seem to many readers as less exciting than some of the traditio-historical reconstructions in some of the other papers. This does not, however, licence us to ignore the need for finding evidence, as far as possible, in scribal practice. From that point of view the present study has merit. It has made the following points about scribes relevant to the issue of the conference:

- A variety of scribes with a variety of different duties are documented from various ancient Near Eastern cultures. Not all of them (e.g., the village scribe) are useful models for suggesting how biblical writings originated, but the work of elite and priestly scribes might be more helpful.

- In Judah the bulk of scribes seem to have been priests or other temple personnel. There were also scribes in the royal or local imperial administration, but even these might have been priestly scribes.

- From the examples of Egypt and Mesopotamia we can see that literature was created because of various needs within the scribal profession. Writings were required for teaching purposes, and we have some examples in which the state (i. e., the king) wanted certain writings edited for state purposes (e.g., the Enuma Eliš under Sennacherib). Yet some of the literature appears to have originated and been developed for aesthetic, creative, and even theological reasons (e.g., the Epic of Gilgamesh).

- Studies relating to the Homeric poems have led to various theories about how oral material gets put into writing. The question of dictation by the oral poet to a scribe is a model that has been discussed. Although the biblical material was often not in poetic form, the dictation model could still be helpful.

- Yet it has been possible to give a few examples where the development of the text can be witnessed in part because various versions have come down to us, illustrating to some extent the work of scribes in progress. Generally, the progress is from shorter to longer, from simpler to more complex, but this is not invariable: there are examples in which later versions are shorter, though in some cases this is because of deliberate editing for particular reasons.

With regard to the relationship between the $\mathrm{P}$ document and the books of Chronicles, the following points can be made:

- $\quad$ Both P and Chronicles appear to be priestly products. P is certainly from the priests, though the author(s) of Chronicles might be individual(s) close to the priesthood without being priest(s) himself(themselves), similar to the situation of Ben Sira. 
- P seems to be a product of the Persian period in its final form, even though some or even much of the material might well have been from the period of the monarchy. It looks to reflect the province of Judah under Persian rule.

- The author(s) of Chronicles, probably writing in the early Greek period (perhaps a century or two later than P), had a number of sources and influences:

- A version of Samuel and Kings

- The P document (whether as a separate document or as a part of a completed Pentateuch

- Other priestly and temple traditions, perhaps in oral form

- The author's(authors') vision of a utopian theocratic (i. e., priestly) paradise

From these data, which seem generally accepted, we can then embark on the task of analyzing the present text of the Pentateuch. The results of that analysis remain hypothetical in that we have no intermediate documents that fill the gaps. Instead, we have to bridge these gaps by intelligent conjecture (as we have for the past two or three centuries), but as long as these conjectures keep the scribal evidence in mind and built on it, their plausibility is enhanced and can be better compared and evaluated. 